\title{
Stylistics and the Teaching of Advanced English for Senior English Majors
}

\author{
Chuanmei Kang \\ Chongqing Institute of Humanity and Science, China
}

\begin{abstract}
This paper first briefly reviews that stylistics is applied to the teaching of English by scholars both abroad and in china, then discusses what and how to do stylistic analysis, and then by means of three sample analyses it aims at illustrating the view that as an effective method, stylistic analysis is conducive to improving students' abilities of reading and appreciation, and it concludes that it is both necessary and practical to apply stylistics to Advanced English teaching.
\end{abstract}

Index Terms -stylistics, stylistic analysis, sample analysis, Advanced English teaching

\section{INTRODUCTION}

Since last century, pedagogical stylistics has been inherently associated with the teaching of written texts (and especially literary texts) to speakers of English as a second language. R. Carter (2000) put forward the teaching strategies of literature, which includes 5 steps: prediction----cloze procedure-----summary-----forum-----guided rewriting. Some other stylisticians such as H.G. Widdowson (1975), Guy Cook (2000), Urszula Clark \& Sonia Zyngier (2003), etc., are enthusiastic about applying stylistics to the teaching of English to both home and foreign students. The principal aim of stylistics in the classroom is to make students aware of language use within chosen texts, and what characterize pedagogical stylistics is classroom activities that are interactive between the text and the (student) readers (Clark \& Zyngier, 2003).

In China, as early as in 1984, Wang Zuoliang claimed that the course of stylistics may take the place of the 4-year-long "intensive reading" course for English majors. Actually, some other Chinese scholars, such as Hu Zhuanglin (2004), Liu Shisheng (2004), Xu Youzhi (2005), Dong Qiming (2004), Wu Xianyou (2003), etc. have made great efforts to put stylistics to use. Moreover, according to "National Syllabus for University English Majors" (National Advisory Board on University Foreign Language Teaching, 2000), both the New Curriculum and English textbooks attach great importance to improving students' text awareness, style awareness as well as their abilities of reading and appreciation, which is not fully realized in Advanced English teaching as a result of various reasons. We hold that it is both necessary and practical to apply stylistics to Advanced English teaching.

\section{Theoretical Preliminaries}

\section{What is stylistics?}

According to Mick Short, stylistics is an approach to the analysis of (literary) texts using linguistic description. It "aims at providing a methodology of analysis---a clear technique of description which, ideally, will allow any persons to cope with any text they want to study, a procedure that can ensure that no items of stylistic significance is overlooked. It replaces a sporadic approach with a systematic one and seeks to avoid over-reliance on intuitive ability in stylistic analysis" (Xu, 2004, P.42). It "is concerned both with interpretation and with the codes themselves; with both what the text means and why and how it means what it does" (Cook, 2000, P.152). Rooted in linguistics, stylistics is a comprehensive study of the particular linguistic features of a text or a writer and it is relatively scientific, objective and effective in dealing with texts.

What is stylistic analysis?

"Stylistic analysis, by starting with linguistic facts, relates description to interpretation and formal features to their artistic function" (Xu, 2004, P.18). "The goal of most stylistic studies is not simply to describe the formal features of texts for their own sake, but in order to show their functional significance for the interpretation of the text; or in order to relate literary effects or themes to linguistic 'triggers' where these are felt to be relevant"(Wales, 2001, P.372-373). It lays stress on the study of language functions and the different structures dictated by these functions. "Such linguistic-stylistic analysis can have considerable benefits for the study of the language and thus aids the integration of language and literature study..." (Carter, 2000, P.110). The process of stylistics analysis will be: take the object of study---a text, examine the text carefully, note down its stylistic features, and discuss them in terms of a number of levels of language. Stylistic analysis usually consists of three steps: description, interpretation and evaluation. By describing and interpreting some specific linguistic features of a certain text, readers are in a better position to understand the text; by evaluating those features, readers are more likely to fully appreciate the stylistic or aesthetic effects of a text. So stylistic analysis is generally believed to be systematic, objective and practical. The most 
noteworthy example is M. A.K. Halliday's thesis “Linguistic Function and Literary Style: An Inquiry into the Language of Willam Golding's The Inheritors".

\section{SAMPLE ANALYSES}

Language is often likened to a code. As a code, language is multi-leveled. Apart from the level of semantics, there are some other levels like lexis, grammar, phonology and graphology, which together construct the giant building of language. So style may exist at various levels of language such as phonology/graphology, lexis, grammar and semantics, and any linguistic choice is a potential stylistic marker. (Leech \& Short, 2001) Here are our sample analyses of some texts From English (Huang Yuanshen and Zhu Zongyi, 2001).

1. At phonological level

Typhoon (Book 6) is a narrative text dealing with men caught up in a vicious gale. It traces man's growing awareness of the tremendous power of the typhoon and his final realization of his own impotence in face of such great natural force. In order to render in language the sinister yet mysterious power of the typhoon and man's desperate endeavor to understand it, the author Conrad has employed many cases of sound patterning, especially the use of alliteration.

1) Definition

Alliteration is known as "head rhyme" or "initial rhyme", the parallelism of the initial consonant cluster in stresses syllables in any sequence of neighboring words (Wu, 2015). "As a deliberate phonological device, it is associated mostly with literary, especially poetic language; but it is also found in popular idioms (e.g. rack and ruin; as dead as a doornail), tongue twisters (Peter Piper picked a peck of pickled pepper.) and advertising language (Guinness is good for you)" (Wales, 2001, P.12).

2) Functions

A. for emphasis ( speech is silver, silence is golden)

B. for humorous effect (tongue twisters)

C. for linking together words that are similar in feeling or thought (as cool as a cucumber)

D. for forming a connection of similarity or a connection of contrast (the best laid schemes o' mice and man)

3) Alliteration in the text

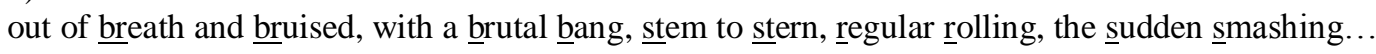

Analysis:

The author make use of words which are intrinsically onomatopoeic, like bang, as well as words which are phonaesthetic in a less direct sense, such as breath and bruised, brutal in which the similarities of sound connote similarities of meaning. The repeated stop consonant /b/ the sudden bursting-out and the heaviness of the harshness of the destructive gale just as the sound /b/ does. And the repeated /br/ sound shows the heavy and depressed mood of people which are victimized by the gale. The repeated consonant cluster/st/ reminds the reader of the enormous frictional force of typhoon to the ship. The sound /s/ indicates the shrill noise of the all-conquering nature power when it is willing to destroy the others. That the sound $/ \mathrm{r} /$ is repeated makes readers form a connection to the regularity of the ship's movement and the articulation of the sound reminds readers of the rolling of ship.

Apart from alliteration, some other sound patterning are employed, such as assonance in ragged mass, the repeated short vowel /æ/ indicates the heaviness and the depressing atmosphere. The continuous use of sound patterning gives the prose certain qualities of poetry. It seems that the terrible experience of man against a ferocious nature deserves a form of language more intense than plain prose. More examples about sound patterning can be found in Salvation (book 5), Appetite (book 5) and so on.

2. At lexical level

Philosophers among carrots (book 6) is written in the form of an essay. Its author manages to unite the two otherwise incompatible human endeavors in a pleasantly ironic way. Highly noteworthy are: 1) the collocational clash in the title, 2) juxtaposition of philosophic terms and household terms and 3) an abundant use of dynamic verbs denoting domestic activities as well as of stative verbs denoting perception or cognition.

The first thing that catches our eye is the title which obviously contains a collocational clash. Normally we do not expect "philosophers" to be found "among the carrots". Our knowledge about the world tells us that philosophers represent the best brains of mankind whereas carrots are perhaps one of the commonest kinds of food-stuff one can think of. Here the semantic incongruity of the two terms not only gives an ironic touch to the whole essay but also focuses the readers' attention on the key issue of the piece: what has college education to do with being a housewife?

This point is further highlighted by the writer's abundant use of the elevated language of philosophy interspersed among terms denoting common household objects and activities. We find words like fantasy, manifestation, metaphysical, philosophy, sense, unity, variety, etc. which are all of Latin origin alongside common core Anglo-Saxon words like apple, cake, cook, cup, eat, shoes, socks, underwear, etc. by placing the two sets of vocabulary side by side, the writer succeeds in forcing us to relate one to the other while maintaining the ironic tone.

It is also noteworthy that a large part of the verbs (finite or nonfinite) used in the essay are stative ones denoting perception or cognition such as: eye, gaze, look, find, know, recall, reflect, remember, see, think, understand, wonder etc. where such a verb is missing, the writer often uses a construction which expresses a cognitive process such as "followed the train of my thoughts" and "indulged in ... fantasies" as if the "I" in the essay is trying to identify herself with the 
immediate world she perceives. In the meantime, we notice that these verbs are accompanied by a number of dynamic ones describing domestic objects and activities such as: clean, comb, cut, dump, eat, immerse, pick up, put on, spray, etc. Both the dynamic verbs and stative ones occur in the structure "as I ..., I ..." so that we have a clear picture of a busy housewife whose training in philosophy has enabled her to perceive and interpret her household routine in the light of great philosophical truths. She seems to be poking fun at herself (a college graduate) as well as at philosophy for it can be quoted to justify any situation. The effect is unmistakably ironic. By employing the above-mentioned linguistic devices, the writer manages to unite the two otherwise incompatible human endeavors in a pleasantly ironic way.

Another example at the lexical level can be found in Daydreams of What You'd Rather Be (Book 6). The author of the text, Lance Morrow, discusses man's yearning to escape from the self to be something different. This conflict between the self and antiself is demonstrated in part by the author's choice of a restricted self of lexical items depicting man's preoccupation with this issue. Lance Morrow adopts overlexicalization to highlight the major theme of the text. Overlexicalization refers to the availability, or the use of profusion of terms for an object or concept(Roger Fowler,1986). In other words, it is the use of synonyms or near-synonyms to refer to the same thing. When it happens in a text, the particular set of vocabulary and the idea it stands for are foregrounded. In Daydreams of What You'd Rather $B e$, the key word "antiself", repeated ten times, is accompanied by its synonyms and near-synonyms such as alternative self(twice), self renewal, self annihilation, the selves we might be, endless series of selves, everything that we are not, soul's next life, what you'd rather be, etc.. And it is also accompanied by the verb phrases to be something else, to leap out of the interminable self and into another skin, another life etc. All these expressions contain the feature /-self/, so man's daydream of being someone other than the self is extensively lexicalized. Its overlexicalization in the text seems to create an extremely active antiself, existing in man's fancy, fantasy, dream, imagination, impulsive moments, which form another set of terms overlexicalized in this text. Since the second set of terms all describe man in his unconscious or half-conscious state, they serve to symbolize the ultimate futility of man's yearning. It seems that by the use of a profusion of terms in these semantic fields the author is able to draw the reader's attention to his theme of man's estrangement from himself.

3. At syntactical level

The power of habit argues that although a habit is developed after birth, it becomes actually no less an inborn quality of a human creature than his character, and it can control one's behavior as powerfully as one's character (Huang, 2001). The author makes a consistent use of schematic patterning which, especially the use of parallelism, highlights the major arguments of the essay.

(1) Definition

Parallelism is defined as "consisting of phrases or sentences of similar constructions and meaning placed side by side, balancing each other". Parallelism may appear at the word, phrase, or clause level. The usual way to join parallel structures is with the use of coordinating conjunctions such as "and" or "or". (Dictionary of Literary Terms. qtd. in English (Book 6), Huang, 2001, p. 57)

(2) Functions

A. Contrast (opposite in meaning)

Speech is silver; silence is golden.

Not that I loved Caesar less, but that I loved Rome more. (Julius Caesar)

B. Similarity

Reading maketh a full man;

conference a ready man; and

writing an exact man. (Proverb by Francis Bacon)

C. Building up a climax and expressing strong emotions

"Let every nation know, whether it wishes us well or ill,

that we bear any burden,

meet any hardship,

support any friend,

oppose any foe to assure the survival and

the success of liberty."

(John F. Kennedy, Inaugural Address, http://www.presidency.ucsb.edu/ws/?pid=8032)

(3) Parallelism in the text

Example 1:

"It alone is what keeps us all within the bounds of ordinance;

It alone prevents the hardest and most repulsive walks of life from being deserted by those brought up to tread therein

It keeps the fisherman and deckhand at sea through the winter;

It holds the miner in his darkness, and ...

(It) nails the countryman to his log-cabin and his lonely farm through all the months of snow;

It protects us from invasion by the natives of the desert and the frozen zone;

It dooms us all to fight out the battle of life upon the lines of our nurture or our early choice, and to make the best of a pursuit that disagrees, because there is no other for which we are fitted, and it is too late to begin again 
It keeps different social strata from mixing.” (Huang, 2001, p. 52)

Analysis:

(1) The list seems to be an open-ended one. We feel as if more sentences describing the power of habit could be added to them. In other words, habit could display a greater power than the space would allow the writer to mention. Affected by the power of habit, the writer seems to get into the habit of using the "It is / does..." structure unconsciously.

(2) The non-human pronoun "it", serving as the subject or the doer of an action instead of the object or receiver, seems to make habit the all-powerful initiator of actions whereas human beings are reduced to nothing but the affected participants of these actions. People are dominated, as it were, by their own habits. Here, parallelism helps to strengthen James' argument that our habits constrain our behavior. So it is of great importance for us to develop useful habits as early as possible.

The schematic patterning gives the prose a regularly measured rhythm, adding much to the poetic flavor of the text. James' repeated use of the same structure helps to build up a climax, thus contributing much to the theme of the text: the enormous power of habit.

Example 2

“...you see the professional mannerism settling down

on the young commercial traveler

on the young doctor

on the young counselor-at-law

... you see the little lines of cleavage running

through the character

the tricks of thought

the prejudices

the ways of the "shop"”'(Huang, 2001, p.52)

Analysis:

(1) Parallelism often goes hand in hand with repetition, which is fully revealed in the above example. The same sentence structure "you see..." is repeated in the next sentence, the prepositional phrase "on the young ..." is repeated twice, and parallelism is employed after the prepositional phrase "through ...."

(2) They are used for emphasis and emotional appeal. It shows that peculiar professional habits as well as traits of a person's character are truly formed at an early age. It goes without saying that habit concerns us all, such as a businessman, a doctor, a lawyer, etc. The reader seems to be led step by step to accepting the writer's view by the latter's clever manipulation of the language.

The same kind of schematic patterning runs through the whole essay to emphasize the content, to express strong emotions and to give balance to the writing.

\section{Implications of This Study IN THE TeACHING OF Other ENGLish Courses}

"Stylistics has come to be used as a significant teaching tool in language and literature studies for both native and foreign speakers of English" (Wales, 2001, P.273). Known as systematic, objective and practical, stylistics has come to be used as a significant teaching tool in the senior English major classes. It is widely used in the teaching of such courses as literature, reading, writing, oral speaking and translation as well, and it will play a big role in the field of teaching.

\section{CONCLUSion}

The stylistic approach to advanced English teaching enables students both to understand and appreciate those texts, and to improve their competence in the English language. Short (1983) refers to such an approach as "a powerful double-edged tool" for the teacher and explains that "by showing how meanings come about he increases enjoyment and sensitivity to good literature; at the same time he increases the students explicit awareness of the general norms and conventions governing English usage" (Short, 1983, p.73). This approach is particularly suitable to Chinese students who have been learning English grammar carefully and systematically. Their familiarity with linguistic terminology will enable them to cope with the detailed and fairly technical stylistic description with little difficulty. In addition to the above, in stylistic analysis students are always asked to base their interpretation and comment on careful and systematic analysis of the language of the text so as to eliminate impressionistic remarks. This requirement will enable students to learn to substantiate argument with evidence and helps students to cultivate habits of logical thinking and objective analysis. Thus, it lays a good foundation for students to carry out research in a scientific way in the future. So it is necessary and feasible to apply stylistics to English teaching (especially advanced English teaching) in China.

\section{REFERENCES}

[1] Cai Jigang. (2001). A Contrastive Study of English and Chinese Writing. Shanghai: Fudan University Press.

[2] Carter, R. (2000), Linguistic Models, Language, and Literariness: Study strategies in the teaching of literature to foreign 
students. In C.J.Brumit and R.A.Carter(eds.): Literature and Language Teaching. Oxford: Oxford University Press.

[3] Christopher Brumfit, \& R.Carter. (2000), Literature and Language Teaching. Shanghai: Shanghai Foreign Language Education Press.

[4] Chen Shifa \& Dongyeshengshi. (2009). A Stylistic Model to the Teaching of Advanced English. Kunming: Journal of Yunnan Agricultural University. Vol4, Pp.56-61, 80.

[5] Clark, Urszula \& Sonia Zyngier. (1996). Towards a Pedagogical Stylistics. Language and Literature, Vol. 12, No. 4, 339-351 (2003) Martin's.

[6] Cook, Guy. (2000). Texts, Extracts, and Stylistic Texture, In Christopher Brumfit, \& R. Carter. .Literature and Language Teaching. Shanghai: Shanghai Foreign Language Education Press.

[7] Dong Qiming. (2004). The Application of Stylistic Analysis in the Close Reading Course for Senior English Majors. Wang Shouyuan, Guo Hong.etc. The Development of Stylistics Research in China. Shanghai: Shanghai Foreign Language Press.

[8] Douthwaitej. (2000).Towards a Linguistic Theory of Fore-grounding. Alessandria: Edizioni dell' Orso. P.19.

[9] Fang Yan. (1998). A Brief Discussion of Genre. Shanghai: Journal of Foreign Languages. Vol 1. Pp: 18-23.

[10] Fowler,Roger. (1996). Linguistic Criticism. Oxford: Oxford University Press.

[11] Hu Zhuanglin \& Liu Shisheng. (2004). The Development of Stylistics Research in China. Wang Shouyuan,Guo Hong.etc. The Development of Stylistics Research in China. Shanghai: Shanghai Foreign Language Press.

[12] Hu Zhuanglin. (2000). Theoretical Stylistics. Beijing: Foreign Language Teaching and Research Press.

[13] Huang Yuansheng \& Zhu Zhongyi. (2001). English. Shanghai: Shanghai Foreign Language Press.

[14] Kay,H,et al. (1998). Genre: What Teachers Think. ELT Journal. Vol52 (4), Pp: 308-314.

[15] Kennedy, John F. Inaugural Address, 5/1/2018. http://www.presidency.ucsb.edu/ws/?pid=8032.

[16] Lambrou, M,.Stockwell, P. (2007). Contemporary Stylistics. London: Continuum.

[17] Leech, Geoffrey N. \& M. Short. (2001), Style in Fiction: A Linguistic Introduction to English Fictional Prose. Peking: Foreign Language Teaching and Research Press.

[18] Leech, G. (2008). Language in Literature: Style and Foregrounding. London: Routledge.

[19] Liu Shisheng. (2004). Study on English Varieties and English Thinking. The $4^{\text {th }}$ National Stylistics Annual Conference. Kaifeng, Henan.

[20] Luo zhaohui. (2013). The Application of Stylistic Approach to the Intensive Reading for Senior English Majors. Guangzhou: Journal of Guangdong Agriculture Industry Business Polytechnic. Vol29 (02). pp: 33-37.

[21] M.A.K, Commings, M., R. Simmons. (1983). The Language of Literature: A Stylistic Introduction to the Study of Literature. Oxford: Pergman Press.

[22] Mills, Sara. (1995). Feminist Stylistics. London: Routledge.

[23] National Syllabus for University English Majors. (2000). Shanghai: Shanghai Foreign Language Education Press.

[24] Nida Eugene A. (1993). Language, Culture and Translating. Shanghai: Shanghai Foreign Language Education Press

[25] Qin Xiubai. (2002). Essentials of English Stylistics. Shanghai: Shanghai Foreign Language Education Press.

[26] Schank RC, Abelson RP. (1977). Scripts, plans, goals, and understanding: An inquiry into human knowledge structures. New Jersey: Lawrence Erlbaum Associates.

[27] Short, M. H. (1983). Stylistics and the Teaching of Literature. In C. J. Brumfit(ed.). Teaching Literature Overseas: Language Based Approaches. Oxford: Pergamon.

[28] Short, M. (1997). Exploring the Language of Poems, Plays and Prose. Harlow: Addison Wesley Longman Limited.

[29] Swales, John M. (1990). Genre Analysis----English in Academic and Research Settings. Cambridge: Cambridge University Press.

[30] Toolan. M. (1990). The Stylistics of Fiction. London: Routedge.

[31] Wales, Katie. (2001). A Dictionary of Stylistics. Ha,rlow: Pearson Education Limited.

[32] Wang Feng. (2016). Review on Major Issues in English Stylistics. Tianjin: Journal of Tianjin Foreign Language University., Vol23 (03), pp:77-79.

[33] Wang Shouyuan. (2000). Essentials of English Stylistics. Jinan: Shandong University Press.

[34] Weber, Jean Jacques, Ed. The Stylistics Reader: From Roman Jakobson to the Present. New York: St.

[35] Werth, P. (1999). Text Worlds: Representing Conceptual Space in Discourse. London: Longman.

[36] Widdowson, H. G. (1975), Stylistics and the Teaching of literature. London: Longman.

[37] Wood. B. Dan. (2010). The Myth of Presidential Representation. Cambridge: Cambridge University Press

[38] Wu Xianyou. (2003). The Theoretical Framework and Application of General Stylistics. Xi an: Foreign Language Education.

[39] Wu Xianyou. (2015). English Rhetoric and Practical Writing. Shanghai: East China Normal University publication.

[40] Xu Youzhi. (2005). English Stylistics. Beijing: Higher Education Press.

Chuanmei Kang, born in Wushan, Chongqing, is currently associate professor of English in Dept. of foreign languages, Chongqing Institute of Humanity and Science. She earned her master degree from Chongqing Normal University, and her main research interests cover literary stylistics, feminist stylistics, and language education. She has published quite a few papers in some Chinese academic journals. 